\title{
Die Hellenistischen Reliefbilder. Theodor Schreiber. Leipzig, 1889. Erste Lieferung.
}

Tris is the beginning of a most important work undertaken by Dr. Schreiber, supported by the Saxon Ministerium des Cultus. Few clusses of monuments of antiquity are less accessible than these reliefs, for which when published we have to trust to drawings such as those of Zoega and Clarac: and yet they are of the greatest importance, not only for the history of myths in antiquity, but also for the study of the development of sculpture and painting in later Hellas. The present part includes no text, but contains ten excellent plates in heliogravure by Dujardin of reliefs at Vienna and in the Palazzo Spada at Rome. Each plate is accompanied by a sketch indicating which parts of the sculpture are restorations, an admirable plan which cannot be too strongly recommended to future editors. Dr. Schreiber's text, when it appears, must needs be of an interest quite unusual : meantime we would commend this great work to the notice of archaeologists and artists.

P. G.

Wiener Vorlegeblätter für archäologische Uebungen. 1888. Отто Benndorf. Vienna, 1889.

THE great value of the Vienna Vorlegeblätter to teachers and students of ancient vases and painting was proved by the rapidity with which the first edition was disposed of : in fact, without them, it is impossible to study Greek vases except in a museum or an extensive archaeological library. The second edition differs from the first in various ways, each set is bound in a cover and can be purchased apart, and the arrangement is altered. The present issue comprises outline drawings of the principal works of the earlier black-figured potters down to Exekias (pls. 1-7), including the wonderful François vase of Florence; Greek and Roman representatives of marriage ceremonies (pls. 8, 9); and a collection of the proposed restorations of the Iliupersis painted at Delphi by Polygnotus (pls. 10-12). Some of these last were scarcely worthy of record or perpetuation.

Like all of the important German archaeological publications, this work is carried out at the cost of a public body,- the Austrian Ministry of Cultus and Education.

\section{P. Paris-1a Sculpture Antique. Paris, 1888.}

P. G.

THIs is the first small hand-book which attempts to give in a concise and popular form the results of recent excavation and research. Its illustrations are admirable, many of them the best that have ever appeared on such a scale : but there are one or two exceptions; fig. 53 gives hardly any notion of its original, and fig. 69 is wrongly restored. The text is mostly concerned with Greek art ; and in this the earlier periods are the most fully treated. The development of types is followed, but no attempt is made to mark distinctions, local or other, among archaic works, even where this is possible. A clear and accurate statement of the evidence of literature and of excavation would have been more valuable to the elementary student than many of the generalities here included. But in spite of all defects, the merits of the work will make it a great acquisition to all students of sculpture. We understand that Miss Harrison will edit an English translation.

E. A. G. 